\begin{tabular}{l} 
JOURNAL OF EMPOWERMENT \\
VOL. 2, No. 1, Juni 2021, h. 89-100 \\
ISSN 2580-0620 (Print) \\
ISSN 2597-9809 (Online) \\
Available Online at https://jurnal.unsur.ac.id/index.php/JE \\
\hline \hline
\end{tabular}

\title{
PENGGUNAAN APLIKASI SEBAGAI MEDIA E-LEARNING REMAJA DI KARANG TARUNA
}

\section{USING THE APPLICATION AS A YOUTH E-LEARNING MEDIA IN KARANG TARUNA}

\author{
Dwi Yulistyanti', Naely Farkhatin², \& Dewi Mustari ${ }^{3}$ \\ ITeknik Informatika Universitas Indraprasta PGRI \\ unindra.dwiyulist@gmail.com \\ 2Teknik Informatika Universitas Indraprasta PGRI \\ naely_farkhatin@yahoo.com \\ 3Teknik Informatika Universitas Indraprasta PGRI \\ mustaridewi@yahoo.com
}

\begin{tabular}{|l|l|l} 
Masuk : 25 Februari 2021 & Penerimaan : 05 Mei 2021 & Publikasi : 01 Juni 2021
\end{tabular}

\begin{abstract}
ABSTRAK
Saat pademi in,i pembelajaran harus tetap dilakukan walaupun tidak di langsungkan di kelas, tetapi dengan pembelajaran yang bersifat online. Pengabdian masyarakat kali ini bertujuan untuk memberikan pengetahuan kepada para Remaja mengenai Aplikasi media E-Learning yang sering digunakan di sekolah dan bisa memilih Aplikasi media pembelajaan yang efektif digunakan dalam E-Learning. Penggunaan Aplikasi (whastapp, zoom, google meet) sebagai media E-Learning ini sudah tidak asing lagi dikalangan remaja di dalam proses belajar mengajar. Tim pelaksana yang berperan sebagai tutor memberikan pengetahuan dan sekaligus melakukan pendampingan pada peserta pelatihan untuk menguasai materi pelatihan. Hal ini memungkinkan para remaja untuk menguasai materi dengan sekaligus melakukan praktik dengan pendampingan instruktur. 8 dari 10 remaja yang mengikuti pelatihan memilih menggunakan whatsapp dengan mempertimbangkan masalah kuota yang dimiliki sehingga pembelajaran bisa tetap berjalan dengan segala keterbatasan terutama masalah biaya pembelian kuota.
\end{abstract}

Kata Kunci : Teknologi; E-learning; Remaja.

\section{ABSTRACT}

During this period, learning must still be carried out even though it is not carried out directly in class, but through online learning. This time, community service aims to provide knowledge to teenagers about E-Learning media applications that are often used in schools and can choose learning media applications that are effectively used in E-Learning. The use of applications (whastapp, zoom, google meet) as an E-Learning medium is no stranger to teenagers in the teaching and learning process. The implementation team, which acts as a tutor, provides knowledge and at the same time provides assistance to training participants to master the training material. This allows the youth to master the material while practicing with the instructor's assistance. 8 out of 10 teenagers who participated in the training chose to use WhatsApp by considering the quota problem they had so that learning could continue with all limitations, especially the problem of purchasing a quota.

Keywords : Technology, E-learning; Youth. 


\section{A. PENDAHULUAN}

Perkembangan Teknologi Informasi beberapa tahun belakangan ini berkembang dengan sangat pesat. Sehingga dengan perkembangan ini telah mengubah paradigma masyarakat dalam mencari dan mendapatkan informasi yang tidak lagi terbatas pada informasi surat kabar, audio visual dan elektronik tetapi juga sumber-sumber informasi lainnya yang salah satu diantaranya melalui media jaringan komputer. Kata media berasal dari bahasa Latin medius yang secara harfiah berarti tengah, perantara, atau pengantar (Azhar Arsyad, 2006). Menurut Suranto (Suratnto, 2005) media ialah suatu sarana yang digunakan untuk menyampaikan pesan dari seorang komunikator kepada komunikan. Sedangkan menurut Sutirman (Sutirman, 2013) media merupakan komponen sumber belajar atau wahana fisik yang mengandung materi instruksional di lingkungan siswa yang dapat merangsang siswa untuk belajar. Menurut Azhar Arsyad (Azhar, 2011 ) fungsi utama media pembelajaran adalah sebagai alat bantu mengajar yang turut mempengaruhi iklim, kondisi, dan lingkungan belajar yang ditata dan diciptakan oleh guru.Penggunaan Aplikasi sebagai media dalam proses pembelajaran tidak harus dihadiri oleh seorang guru. Karena tanpa seorang guru proses pembelajaran dapat berlangsung. Dengan kata lain siswa dapat melakukan proses pembelajaran secara individual dengan materi pembelajaran yang telah disusun sesuai dengan kesiapan siswa. Sehingga mampu mempertunjukkan perilaku kesiapan siswa sesuai yang diharapkan. Dalam situasi seperti ini guru dapat berdiri di belakang layar dan dapat lepas tangan dari tugas-tugasnya sebagai pemberi informasi. Karena tugasnya telah digantikan oleh Aplikasi (whatsapp, zoom, goggle meet) sebagai pembelajaran. Jadi, dengan Aplikasi (whatsapp, zoom, goggle meet) sebagai media pembelajaran diharapkan siswa dapat interaktif. Menurut Jogiyanto dikuip oleh Ramzi (Ramzi, 2013) aplikasi merupakan penerapan, menyimpan sesuatu hal, data, permasalahan, pekerjaan kedalam suatu sarana atau media yang dapat digunakan untuk menerapkan atau mengmplementasikan hal atau permasalahan yang ada sehingga berubah menjadi suatu bentuk yang baru tanpa menghilangkan nilai-nilai dasar dari hal data, permasalahan, dan pekerjaan itu sendiri. Menurut Arif Akbarul Huda (Arif, 2013) komponen aplikasi merupakan bagian penting dari sebuah Android. Setiap komponen mempunyai fungsi yang berbeda, dan antara komponen satu dengan yang lainnya bersifat saling berhubungan. Jadi, dengan Aplikasi(whatsapp,zoom, goggle meet) sebagai media pembelajaran diharapkan siswa dapat interaktif.

Sehingga dapat berfikir kritis dan tidak mengalami kebosanan saat proses pembelajaran berlangsung. Supaya materi pembelajaran yang ada akan tersampaikan dengan baik dan sesuai dengan tujuan awal. Perkembangan teknologi yang pesat memberikan kemudahan pengguna dalam berinteraksi satu sama lain. Jika pengguna tidak mengikuti perkembangan teknologi yang ada, maka pengguna akan tertinggal dengan pengguna lain yang mengikuti perkembangan teknologi. Kemajuan teknologi memberikan manfaat bagi pengguna namun juga memberikan kerugian bagi pengguna. Hal itu dapat terjadi karena tidak adanya kontrol dalam mengikuti perkembangan teknologi yang ada. Manfaat dari penggunaakan aplikasi (whatsapp, zoom, goggle meet) tentunya dapat membantu proses belajar daring saat ini. Sedangkan salah satu kerugian dari pengunaan aplikasi (whatsapp, zoom, goggle meet) tentunya harus mengeluarkan biaya untuk membeli paket data.

Keberhasilan proses pembelajaran bergantung kepada penggunaan sumber daya dan media pembelajaran yang sesuai. Jika sumber dan media yang dipilih serta dipersiapkan dengan tepat dapat memenuhi kebutuhan dengan baik. Yang menimbulkan motivasi positif peserta didik, mejelaskan dan menggambarkan isi subjek, dan menggambarkan kinerja individual. Maka kedudukan Aplikasi sebagai media dalam pembelajaran tidak dapat dianggap sepele. 
Permasalahan yang di hadapai oleh remaja karang taruna adalah menentukan media pembelajaran yang sesuai dengan kebutuhan dan bisa menghemat kuota serta ketidak tauan dalam penggunaan media pembelajaran online. sehingga tujuan dari kegiatan ini. Pertama memberikan pelatihan bagaimana cara menggunakan aplikasi (WhatsApp, Google Meet, Zoom). Karena kondisi saat ini yang tidak memungkinkan untuk bisa belajar tatap muka di kelas. Maka mau tidak mau pembelajaran harus dilakukan secara online. Kedua untuk meningkatkan kompetensi para Remaja agar dapat mengetahui penggunaaan Aplikasi (WhatsApp, Google Meet, Zoom) media pembelajaran yang produktif.

Setelah menganalisis dan memahami permasalahan yang ada, maka kami menawarkan solusi yang dapat memecahkan permasalahan tersebut. Solusi yang ditawarkan yaitu Pertama dengan adanya pelatihan mengenai penggunaan aplikasi sebagai media pembelajaran online (Daring), dapat meningkatkan pengetahuan remaja mengenai manfaat aplikasi tersebut. Kedua memberikan pengetahuan betapa pentingnya pengetahuan mengenai teknologi dan dapat mempermudah dalam pembelajaran jarak jauh walaupun tidak belajar tatap muka tapi masih bisa mendapatkan ilmu. Ketiga memberikan pelatihan kepada para remaja di rw.05 kp.kekupu rangkepan jaya depok. Keempat pengabdian dilakukan di salah satu tempat tinggal tim pengabdian masyarakat karena sering mendengar keluhan para remaja karang taruna dalam melaksanakan pengajaran dari sekolah.

Luaran yang ditargetkan dari kegiatan Iptek Kepada Masyarakat ( $\left.I_{b} M\right)$ adalah Pertama peningkatan kompetensi para Remaja agar dapat mengetahui Penggunaaan Aplikasi media pembelajaran yang produktif. Kedua peningkatan pengetahuan para Remaja agar lebih selektif dalam penggunaan Aplikasi media Pembelajaran yang sehat dan baik.

\section{B. METODE}

Sebagaimana telah teridentifikasi dalam pendahuluan mengenai permasalahan yang dihadapi mitra yaitu kurang nya pengetahuan tentang tata cara penggunaan Aplikasi media pembelajaran yang baik dan benar dikalangan remaja RW $05 \mathrm{Kp}$.Kekupu Rangkepan jaya Depok, maka antara pelaksana dan mitra telah tercapai suatu kesepakatan untuk mengatasi permasalahan tersebut.

Adapun cara yang telah disepakati dan ditempuh adalah dengan pemberian sosialisasi kepada para remaja mitra. Dosen memberikan sosialisasi kepada remaja karang taruna yang dihadiri oleh anggota karang taruna sebanyak 8 orang, di RW 05 KP. Kekupu yang di bantu oleh mahasiswa yang bertugas menyiapkan segala keperluan pada saat pelatihan belangsung. Sosialisasi ini memberikan pengetahuan penggunaan aplikasi media pembelajaran. Kegiatan pengabdian kepada masyarakat ini diselenggarakan di lokasi Karang Taruna mitra dengan menggunakan pendekatan Sosialisasi. Pendekatan ini memungkinkan para peserta untuk memahami langsung materi pelatihan yang diberikan oleh tim pelaksana dari Universitas Indraprasta PGRI. Dalam pemberian Sosialisasi kepada para Remaja mitra dilaksanakan secara daring yaitu mengunakan aplikasi Zoom dikarenakan kondisi pandemi yang semakin meningkat. Sosialisasi ini diberikan tentang Pengetahuan Penggunaan Aplikasi media dalam pembelajaran daring yang diselenggarakan di lokasi Karang Taruna RW 05 Kp.Kekupu Rangkepan Jaya Depok. Adapun partisipasi mitra yaitu remaja Karang Taruna dengan mendengarkan dari aplikasi Zoom di tempat masing-masing baik menggunakan handphone/telefon genggam atau Laptop. Dalam kesempatan tersebut para peserta pelatihan Remaja Karang Taruna RW 05 Kp.Kekupu Rangkepan Jaya Depok mempelajari dan mendapat pendampingan secara intensif mengenai cara-cara 
menggunakan dan belajar tentang penggunaan Aplikasi media pembelajaran yang baik dan benar.

\section{HASIL ATAU PEMBAHASAN}

Perkembangan Teknologi Informasi beberapa tahun belakangan ini berkembang dengan sangat pesat, sehingga dengan perkembangan ini telah mengubah paradigma masyarakat dalam mencari dan mendapatkan informasi yang tidak lagi terbatas pada informasi surat kabar, audio visual dan elektronik tetapi juga sumber-sumber informasi lainnya yang salah satu diantaranya melalui media jaringan komputer. Salah satu bidang yang mendapatkan dampak yang cukup berarti dengan perkembangan teknologi ini adalah bidang Pendidikan. Pendidikan merupakan suatu proses komunikasi dan informasi dari pendidik kepada peserta didik yang berisi informasi-informasi pendidikan, yang memiliki unsur-unsur pendidik sebagai sumber informasi. Media sebagai sarana penyajian ide, gagasan dan materi pendidikan serta peserta didik itu sendiri. Dalam kondisi pandemi seperti ini, khususnya yang berhubungan dengan pembelajaran memang menjadi masalah. Permasalahan akan muncul disaat pembelajaran tidak berialan dengan lancar.

Pembelajaran online memang akan menimbulkan berbagai macam masalah saat pemilihan aplikasi pembelajaran yang kurang tepat. Ada banyak aplikasi yang bisa digunakan agar pembelajaran tetap berlangsung seperti (WhatsApp, Google Meet, Zoom). Namun pengajar harus mempertimbangkan banyak hal dalam memilih aplikasi tersebut. Menggunakan WhatsApp Grup (WAG) memang mudah dalam merealisasikannya, karena saat ini siapa pengguna telpon seluler yang tidak memiliki aplikasi tersebut, hampir semua pengguna telpon seluler memiliki aplikasi WhatsApp mulai dari Telpon Seluler termurah sampai dengan termahal. Guru dan pelajar dapat menggunakan aplikasi tersebut dalam pembelajaran online. Namun kendalanya adalah biasanya pengajar hanya akan mengirim file materi pembelajaran atau video pembelajaran, jarang sekali siaran langsung. Namun walaupun begitu banyak guru yang memakai WhatsApp sebagai media pembelajaran online, karena setiap siswa pasti memiliki aplikasi WhatApp. Karena pembelajaran menggunakan WhatsApp lebih sedikit menggunakan kuota karena biasanya hanya bentuk file materi. Tentunya itu akan sangat berpengaruh dengan siswa, kenapa karena belum tentu semua siswa memiliki kuota yang banyak, sehingga dengan adanya pembelajaran lewat daring menggunakan WhatsApp sangat di gemari oleh pengajar walaupun memiliki banyak kekurangan. Media pembelajaran lainya seperti Zoom, tentu saja sangat bagus karena siswa dengan pengajar bisa langsung berkomunikasi melalui video call. Namun tentunya akan menjadi masalah jika jaringan tidak stabil dan memerluka kuota cukup banyak. Tentu saja semua tergantung kesepakatan bersama antara pengajar dengan siswa mau menggunakan media pembelajaran yang menurut mereka membantu dalam pembelajaran di masa pandemi sepertinya, dan alangkah lebih baik lagi jika di kombinasi sesuai dengan kebutuhan. Oleh sebab itu, remaja di RW $05 \mathrm{Kp}$.Kekupu yang mengeluh tentang pembelajaran daring/E-Learning, mereka belum terlalu mengerti bagaimana penggunaan Aplikasi-Aplikasi media E-Learning. Dengan adanya pelatihan mengenai pengunaan media pembelajaran, semoga bisa membantu remaja di RW 05 Kp.Kekupu agar terbiasa mengunakan media tersebut untuk kepentingan pembelajaran. Adapun hal-hal yang perlu di ketahui para remaja Karang Taruna sebagai pengetahuan tentang apa itu media pembelajaran menggunakan aplikasi daring seperti (WAG, Zoom, Google Meet).

Pertama, Istilah teknologi sendiri berasal dari perpaduan dua kata yaitu techne dan logos. Kata techne dalam bahasa Yunani memiliki arti keterampilan sedangkan logos berarti ilmu. Secara singkatnya, pengertian teknologi berarti ilmu yang mempelajari 
tentang keterampilan. Penggunaan istilah teknologi sendiri diadopsi dari bahasa Inggris "Technology" sejak abad ke-20 yang bersamaan dengan berakhirnya Revolusi Industri Kedua.9 Perkembangan dapat dilihat dari aneka inovasi teknologi yang ada saat ini.

Kedua, Aplikasi sering juga disebut sebagai perangkat lunak, merupakan program komputer yang isi instruksinya dapat diubah dengan mudah. Aplikasi pada umumnya digunakan untuk mengontrol perangkat keras (yang sering disebut sebagai device driver). Didalam Perkembangannya Aplikasi Tidak Hanya Yang ada Di dalam Komputer Melainkan Sekarang Sudah Banyak Aplikasi Berjalan di Telepon Genggam (HP) Dengan Operating System Android. Secara umum aplikasi dapat dibagi menjadi 3 tingkatan yaitu tingkatan program aplikasi (application program misalnya Microsoft Office), tingkatan sistem operasi (operating system misalnya Microsoft Windows), dan tingkatan bahasa pemrograman (misalnya PHP).

Apa sebetulnya fungsi dan manfaat aplikasi? Di era modern 1. Untuk Mempermudah Pekerjaan: Dengan aplikasi, maka pekerjaan Anda pun lebih mudah. Anda hanya tinggal mencari nama aplikasi atau fungsi dari suatu aplikasi di Play Store dan App Store dan mendowloadnya.10 2. Sebagai Media Hiburan: Dengan kehadiran aplikasi sebagai media hiburan, kamu tidak akan bosan di manapun kamu berada. Maka dari itu, tidak mengherankan apabila saat ini, ada banyak orang yang tidak pernah merasa bosan pada saat menunggu. 3. Untuk Mendapat Pembaharuan Kabar (Update berita): Melalui aplikasi, Anda juga bisa mendapatkan kabar-kabar terkini. Apa saja? Misalnya, aplikasi baca berita atau podcast. Anda bahkan bisa menyalakan notifikasi supaya tidak ketinggalan berita-berita terbaru di ponsel. Jadi, Anda tetap bisa update perkembangan berita di manapun Anda berada. 4. Untuk Media Pertemanan atau Komunikasi: Aplikasi juga mampu mendekatkan jarak di antara kita, lho. Contohnya seperti Whatsapp, Line, dan sebagainya. Dengan adanya aplikasi, Anda bahkan bisa berkomunikasi dengan orang-orang yang letaknya jauh. 5. Mempermudah Kehidupan: Harus diakui bahwa keberadaan berbagai aplikasi sangat mempermudah kehidupan kita semua bukan? Misalnya, aplikasi yang bisa membantu kita melihat peta, memesan makanan, memesan tiket, dan sebagainya. Selain punya kegunaan, aplikasi juga punya beragam efek buruk.

Efek-efek buruk aplikasi adalah sebagai berikut: 1. Mengumpulkan Data Pribadi : Sering dengar kata scamming? Kata yang satu itu memiliki makna penipuan. Penipuan bisa berawal dari data pribadi yang disalahgunakan, dan aplikasi dapat menjadi sumber bencananya. Aplikasi-aplikasi tertentu meminta izin pada pengguna buat mengumpulkan data pribadi mereka. Ini bisa menjadi momok karena aplikasi-aplikasi itu dapat mengakses kontak, mengakses data pribadi pengguna, dan juga menggunakannya untuk hal-hal yang tidak diinginkan.11 2. Membawa Virus: Ada banyak aplikasi yang membawa virus, lho. Virus dapat berbahaya bagi ponsel atau komputer Anda, bisa merusak ponsel atau komputer, dan juga dapat menghilangkan data-data penting. 3. Membuat Anda menjadi ketagihan: Aplikasi dapat membuat seseorang menjadi ketagihan. Pasalnya, aplikasi memberikan beragam hal ajaib yang tidak bisa dilakukan oleh manusia, seperti misalnya berhubungan dengan orang lain atau memberikan pengalaman gim seru. 4. Merusak Mata: Grafis-grafis yang ada pada aplikasi dapat merusak mata apabila dilihat dalam intensitas berlebihan. Contohnya seperti mata minus, dan sebagainya.

Aji (Syah, 2020) menyatakan bahwa banyak negara yang pemerintahnya terpaksa memutuskan untuk menutup sekolah dari sekolah dasar sampai perguruan tinggi, termasuk di Indonesia. Nadiem Makarim sebagai Menteri Pendidikan dan Kebudayaan Indonesia akhirnya mengeluarkan surat edaran penanganan Covid-19 di bidang pendidikan, yaitu dengan menginstruksikan kepada Dinas Pendidikan tingkat provinsi, kabupaten maupun kota, lembaga layanan pendidikan tinggi, dan yang terkait dengan 
pendidikan melalui Surat Edaran No. 3 Tahun 2020 tentang Pencegahan Covid-19 Pada Satuan Pendidikan. Upaya ini dilakukan dengan tujuan untuk meminimalisir kontak langsung dengan banyak orang, dan mencegah penyebaran coronavirus (Adhi Wicaksono, 2020). Akhirnya sistem pembelajaran diubah menjadi online atau dalam jaringan (daring), yang membuat guru harus memutar otak untuk mengubah sistem pembelajaran yang sudah dipersiapkan di jauh-jauh hari. Tidak hanya guru, siswa pun harus terbiasa untuk menerima materi secara daring, dan mengerjakan secara mandiri di rumah masing-masing. Selain itu, dalam sistem pembelajaran daring, anak-anak dibimbing oleh orang tuanya, yang artinya tugas orang tua di rumah bertambah dan harus ekstra dalam membimbing pembelajaran anak-anak. Dalam hal ini, siswa dan orang tua siswa harus memiliki komunikasi yang baik untuk bekerja sama mensukseskan sistem pembelajaran daring di saat pandemi ini.

Menurut Ermayulis (Ermayulis, 2020), pembelajaran daring merupakan pembelajaran yang dilakukan secara jarak jauh dan online tanpa melakukan tatap muka, dan dengan menggunakan aplikasi-aplikasi pembelajaran yang sudah tersedia. Salah satunya menggunakan aplikasi WhatsApp. Penggunaan WhatsApp sebagai media pembelajaran sudah banyak digunakan di berbagai sekolah, terutama di sekolah dasar. Berikut merupakan fitur dan fungsi dari WhatsApp menurut Pustikayasa (Pustikayasa, 2019):

1. Pesan: Fitur ini digunakan untuk berkim pesan kepada pengguna lain dengan koneksi internet.

2. Chat Grup: Fitur ini dapat digunakan untuk pembuatan grup yang terdiri dari nomor ponsel yang sudah terdaftar dalam WhatsApp untuk memudahkan pengguna berkomunikasi dengan angota dalam grup tersebut.

3. WhatsApp Web dan Desktop: WhatsApp juga dapat digunakan oleh pengguna melalui browser komputer atau langsung pada komputer dengan syarat WhatsApp pada ponsel harus dalam keadaan aktif.

4. Panggilan Suara dan Video: Fitur ini dapat digunakan untuk meakukan panggilan suara dan panggilan video di selurh dunia dengan menggunakan koneksi internet. Panggilan dapat dilakukan dengan 8 orang secara langsung.

5. Foto dan Video: Pengguna dapat membagikan foto dan video kepada pengguna baik secara personal maupun ke dalam grup.

6. Audio: Pengguna dapat menggunakan fitur ini untuk membagikan file berbentuk suara.

7. Dokumen: Pengguna dapat membagikan dokumen kepada pengguna lainnya secara personal maupun ke dalam grup.

8. Enkripsi End to End: Fitur ini guna untuk sistem keamanan bagi pengguna. Adapun kelebihan-kelebihan pada WhatsApp sebagai media pembelajaran (Pustikayasa, 2019), yaitu:

1. Tidak harus login terlebih dahulu untuk mengakses WhatsApp jika nomor ponsel sudah terdaftar.

2. Langsung terhubung dengan kontak pengguna WhatsApp lainnya.

3. Pengguna dapat bertukar kontak dengan pengguna lainnya.

4. Dapat membagikan lokasi terkini.

5. Dapat mengirim pesan ke banyak orang (broadcast).

6. Aplikasi ini tidak menguras kuota terlalu banyak.

7. Guru dan siswa dapat berdiskusi dan bertanya jawab dengan lebih rileks.

8. Dapat melihat siapa saja yang sudah membaca dan siapa yang tidak aktif.

9. Guru dapat mengirimkan dokumen, foto, audio ataupun video sebagai materi pembelajaran kepada siswa melalui grup WhatsApp. 
10. Guru dan siswa dapat melihat dan mengulang materi pembelajaran melalui HP dengan mudah.

11. Guru dan siswa dapat berkomunikasi kapan saja dan di mana saja.

Selain itu, Pustikayasa (Pustikayasa, 2019) juga menambahkan bahwa terdapat kelemahan yang ada pada aplikasi WhatsApp:

1. Pengguna harus terhubung dengan layanan internet untuk menggunakan aplikasi ini, jika tidak terhubung akan menghambat proses pembelajaran secara daring

2. Komunikasi hanya dengan chat saja, kapasitas orang terbatas jika ingin bertatap muka secara virtual (video call).

Dari penjelasan di atas, dapat kita lihat beberapa fitur yang dapat digunakan di WhatsApp. Selain itu, adapula kelebihan-kelebihan pada WhatsApp yang digunakan sebagai media pembelajaran daring ada masa pandemi ini. Semua kelebihan tersebut dapat membantu proses pembelajaran daring seperti saat ini. Namun ada pula beberapa kelemahan dari aplikasi WhatsApp yaitu harus terhubung dengan layanan internet dan kapasitas orang yang terbatas untuk melakukan panggilan.

Media pembelajaran lainya seperti zoom, tentu saja sangat bagus karena siswa dengan pengajar bisa langsung berkomunikasi melalui video call. Namun tentunya akan menjadi masalah jika jaringan tidak stabil dan memerluka kuota cukup banyak. Tentu saja semua tergantung kesepakatan bersama antara pengajar dengan siswa mau menggunakan media pembelajaran yang mana yang menurut mereka membantu dalam pembelajaran dimasa pademi sepertinya, dan alangkah lebih baik lagi jika di kombinasi sesuai dengan kebutuhan.

COVID-19 (QA, 2020) adalah penyakit menular yang disebabkan oleh jenis coronavirus yang baru ditemukan. Virus baru dan penyakit yang disebabkannya ini tidak dikenal sebelum mulainya wabah di Wuhan, Tiongkok, bulan Desember 2019. COVID-19 ini sekarang menjadi sebuah pandemi yang terjadi di banyak negara di seluruh dunia (WHO). Di Indonesia (Yunita, 2020) kasus ini pertama kali ditemukan pada dua warga Depok, Jawa Barat awal Maret lalu. Data hingga Sabtu, 28 Maret 2020 jumlah warga yang dinyatakan positif terkena virus corona mencapai 1.155 dan 102 di antaranya meninggal dunia.

Cepatnya penyebaran virus ini di Indonesia menurut Juru Bicara pemerintah untuk penanganan COVID-19, Achmad Yurianto karena banyak warga yang tak mengikuti imbauan untuk tetap di rumah. Utamanya, tetap di rumah dan hanya keluar bila memang benar-benar perlu. Ini penting, terutama bagi orang yang berisiko tinggi, termasuk orang lanjut usia dan yang memiliki riwayat penyakit jantung, tekanan darah tinggi, diabetes, dan paru. Siapapun yang merasa sakit harus tetap di rumah dan mencari pengobatan bila gejala memburuk (Arimacs , 2020).

Ketika kita melakukan pembelajaran secara daring tentunya kita memerlukan media sebagai sarana untuk pembelajaran. Oleh sebab itu berbagai Platfrom digunakan sebagai media pembelajaran oleh sekolah maupun universitas. Salah satu media belajar yang banyak digunakan dalam pembelajaran daring adalah aplikasi Zoom Meeting. Zoom Meeting sendiri merupakan sebuah media pembelajaran menggunakan video. Pendiri aplikasi Zoom Meeting yaitu Eric Yuan yang diresmikan tahun 2011 yang kantor pusatnya berada di San Jose, California (Haqien \& Rahman, 2020). Adapun beberapa kelebihan aplikasi Zoom Meeting adalah sebagai berikut:

1. Kapasitas ruang besar: Proses belajar yang biasanya dalam satu kelas dilakukan oleh sekitar 30-40 orang memang dapat tertampung di aplikasi yang satu ini. Sebab dengan segala fitur yang dimilikinya aplikasi ini mampu menyediakan sebuah pelayanan khusus berupa komunikasi dengan video hingga 1.000 akses bagi anggota dalam satu forum diskusi. 
2. Fitur beraneka ragam: Zoom memiliki fitur akses menghidupkan dan mematikan suara serta gambar. Akses ini diklaim cukup berguna bagi para pengguna terutama pada kualitas suara. Saat sebuah diskusi berjalan, tentunya harus menyediakan kondisi yang kondusif untuk kelancaran kegiatan. Fitur mematikan mikrofon pada peserta diskusi dapat menjadi salah satu alternatif tersebut. Anda bisa merekam dan menyimpan video selama meeting berlangsung, mencerahkan warna kulit wajah Anda, mengubah background sesuai dengan yang diinginkan, hingga menjadwalkan pertemuan online.

3. Kualitas video dan suara yang baik: Suatu pertemuan online tentu akan menjadi sangat buruk jika kualitas suara dan resolusi video yang ditampilkan bukan yang terbaik. Bisa-bisa, kita tidak bisa menangkap apa yang lawan bicara ucapkan. Zoom mampu menghadirkan kualitas video yang jernih dan suara yang jelas sehingga akan memudahkan saat sedang berkomunikasi.

4. Mendukung presentasi: Bagi Anda yang ingin menjelaskan atau memahami sebuah materi secara lebih dalam, di dalam aplikasi Zoom Anda bisa mempresentasikan file materi kepada partisipan lainnya. Baik partisipan maupun pemateri bisa mencoret-coret presentasi tersebut sehingga akan lebih mempermudah pendalaman materi. Hal ini sangat berguna dalam proses pembelajaran daring.

Adapun beberapa kelemahan aplikasi Zoom Meeting adalah sebagai berikut:

1. Boros penggunaan kuota data: Boros penggunaan pada kuota data merupakan salah satu kekurangan Zoom. Hal ini dapat teriadi karena akses Zoom yang begitu luas memungkinkan penggunaan data internet yang semakin besar. Sehingga, disarankan bagi anda untuk menyediakan data internet secukupnya. Atau jika perlu gunakan jenis kuota un-limited yang tidak terbatas penggunaan akses datanya. Ada baiknya bagi para pengguna Zoom dalam menggunakan teknologi ini sebijak mungkin. Jika menggunakan ruang pesan masih cukup memungkinkan. Mungkin Zoom dapat dijadikan pilihan selanjutnya jika ingin bertatap langsung secara jarak jauh.

2. Tidak tersedia bahasa Indonesia: Teknologi Zoom tidak menyediakan Bahasa Indonesia sebagai fitur pendukung diskusi maupun siaran langsung. Akses bahasa yang masih mungkin dapat digunakan untuk pengguna ialah Bahasa Inggris, Bahasa Portugis, Bahasa Belanda, dan lain sebagainya. Sehingga akan cukup menyulitkan bagi Anda yang kurang memahami bahasa Inggris. Namun ini bukan suatu masalah serius, sebab dengan adanya Google Translate Anda bisa memahami kalimat bahasa Inggris dengan baik.

3. Rawan data bocor: Sebuah kebocoran data tentunya menjadi salah satu kekurangan Zoom paling menyeramkan yang pernah terjadi. Data yang rawan terkena peretasan dapat berujung pada data pribadi seseorang. Sehingga besar kemungkinan jika memiliki informasi terpenting seperti bisnis, pendidikan, foto, akan dapat dengan mudah tersebar luas di jejaring media sosial. Terlebih jika data tersebut digunakan sebagai tindak kejahatan yang marak terjadi di luar negeri.

Namun bagi anda yang risau dengan salah satu kekurangan ini. Akses yang dapat terkena rawan kebocoran data, dapat ditanggulangi dengan tidak perlu mendaftar akun. Cukup dengan bergabung pada ID Meeting dan Password dari diskusi tersebut. Cara ini diklaim sebagai salah satu solusi bagi anda yang tetap ingin menggunakan Zoom pada mode aman. Dari penjelasan diatas dapat kita lihat beberapa kelebihan aplikasi Zoom yang dapat digunakan sebagai media pembelajaran daring pada masa pandemi COVID-19 seperti kapasitas ruang besar, fitur yang beraneka ragam, kualitas suara dan video yang baik serta mendukung untuk melakukan sebuah presentasi. Semua kelebihan tersebut dapat membatu proses belajar bengajar yang dilakukan secara 
daring akibat pandemi COVID-19. Tetapi selain kelebihan dari aplikasi Zoom itu sendiri terdapat juga beberapa kelemahan yaitu borosnya penggunaan kuota data, tidak tersedianya bahasa Indonesia dan rawannya data bocor. Beberapa kelemahan dari aplikasi zoom tersebut dapat memengaruhi kegiatan belajar mengajar sehingga perlu diperhatikan lagi bagaimana kondisi siswa yang akan mengikuti pembelajaran dengan media pembelajaran Aplikasi Zoom. Jika keadaan siswa belum mendukung untuk menggunakan aplikasi Zoom sebgai media pembelajaran daring pada masa pandemi disarankan untuk tidak memaksakan dan berusaha mencari media pembelajaran daring yang lain.

Google Meet (Rudi Dian Arifin, 2020) adalah layanan konferensi video/ meeting online yang dikembangkan oleh Google. Layanan Google Meet merupakan gabungan dari Google Chat dan Google Hangouts dengan pengembangan yang lebih dikhususkan pada pertemuan online. Oktober 2019, Google Hangouts menghentikan versi klasiknya dan pengguna dapat beralih menggunakan Hangouts untuk versi yang lebih modern. Google Meet diperkenalkan pada bulan Februari 2017 secara diam-diam untuk pengguna iOS (iPhone). Pada bulan berikutnya, Google Meet diperkenalkan secara publik dan dapat di akses melalui browser web, iOS, dan Android. Pada versi gratis, pengguna dapat melakukan pertemuan dengan jumlah maksimal 100 peserta. Sedangkan versi premium/ bisnis, pengguna dapat melakukan pertemuaan dari 100 hingga 250 peserta.

Siapapun yang memiliki akun Google dapat membuat pertemuan atau berpartisipasi dalam meeting online. Untuk alasan keamanan, host memiliki akses penuh dalam sebuah meeting. Host dapat menolak masuk dan menghapus pengguna selama pertemuan berlangsung. April 2020, Google juga telah menambahkan fitur audio peredam bising khusus untuk paket bisnis. Untuk alasan privasi, Google juga menyatakan bahwa tidak merekam ataupun menyimpan video meeting untuk penargetan iklan. Namun informasi dari analisis kebijakan privasi Meet, Google berhak untuk menyimpan durasi panggilan, pengguna yang ikut berpartisipasi, hingga alamat IP pengguna.

Google Meet hadirkan segudang fitur dan manfaat untuk memaksimalkan pengguna dalam melakukan pertemuan online. Simak beberapa fitur ungulan Google Meet berikut ini;

1. Pengguna dapat bergabung dalam sebuah rapat melalui web, aplikasi Android atau iOS (iPhone).

2. Integrasi dengan Google Kalender yang memungkinkan pengguna untuk membuat jadwal rapat.

3. Meungkinkan pengguna untuk berbagi layar untuk kebutuhan presentasi dokumen, spreadsheet, atau presentasi.

4. Tersedia fitur Chat sehingga pengguna dapat melakukan diskusi atau mengirim pesan teks ketika meeting berlangsung.

5. Host memiliki akses penuh untuk menolak atau mengizinkan pengguna untuk terhubung.

6. Panggilan dilakukan enkripsi sehingga keamanan lebih terjamin.

7. Paket $G$ Suite memiliki akses ke banyak fitur yang lebih baik seperti recording, attendance tracking, retention, serta cloud storage yang lebih besar.

Selain integrasi dengan akun Google, Google Meet hadirkan beragam fitur yang memungkinkan pengguna untuk meeting online, presentasi, chatting, hingga recording. Google Meet berusaha menghadirkan layanan dan fitur sesuai dengan keinginan dan kebutuhan pengguna. Meskipun demikian, Google Meet juga tak lepas dari kekurangannya. Berikut beberapa kelebihan dan kekurangan Google Meet yang perlu anda ketahui.

Kelebihan Google Meet 
1. Kemudahan untuk bergabung. Bergabung dalam sebuah meeting di Google Meet terbilang sangat mudah, partisipan dapat bergabung melalui web, aplikasi Android atau iOS.

2. Akses menggunakan akun Google. Mayoritas pengguna Android memiliki akun Google sehingga akses Google Meet akan lebih mudah dan cepat, tanpa harus mendaftarkan diri.

3. Waktu pertemuan cukup panjang. Pertemuan di Google Meet dapat berlangsung selama 60 menit (gratis). Hal ini dirasa jauh lebih baik ketimbang Zoom Meeting yang hanya 40 menit.

4. Terhubung ke Google Drive. Google Meet terintegrasi dengan Google Drive untuk penyimpanan file recording dandokumen yang sekiranya dibutuhkan. Pengguna yang memilih paket premium $G$ Suite dapat merekam dan hasil rekaman tersimpan di Google Drive.

Kekurangan Google Meet

1. Versi gratis tidak support recording. Sayangnya versi gratis dari Google Meet tidak tersedia fitur recording. Berbeda dengan Zoom Meeting dan Skype yang dalam versi gratisnya telah tersedia fitur recording.

2. Berbagi layar terasa berat dan lambat. Ketika melakukan presentasi dengan berbagi layar melalui browser, komputer terasa sangat berat. Mungkin dibutuhkan komputer dengan spesifikasi hardware yang lebih baik agar presentasi terasa lancar.

3. Tidak dapat mengubah layar background. Beberapa layanan konferensi video telah menghadirkan fitur untuk mengubah layar background sehingga visualisasi terlihat lebih menarik. Sayangnya, Google Meet belum menyediakan fitur ini.

4. Belum ada Google Meet versi Desktop. Hingga saat ini, belum tersedia Google Meet versi desktop yang artinya meeting melalui komputer harus dilakukan melalui browser.

Oleh sebab itu, remaja di rw.05 Kp.Kekupu yang mengeluh tentang pembelajaran daring/E-Learning, mereka belum terlalu mengerti bagaimana penggunaan AplikasiAplikasi media E-Learning. Selain juga banyak dari siswa yang mengeluh mengenai banyaknya tugas dari setiap mata pelajaran yang di bebankan ke siswa serta waktu yang pendek untuk pengumpulannya. Masalah yang lainnya adalah mengenai kuota data yang terbatas yang dimiliki oleh siswa sehingga menjadi kendala dalam pembelajaran daring ini. Walaupun kenyataanya sudah mendapatkan bantuan kuota dari pemerintah tetap saja terkadang tidak semua guru menggunakan teleconference, banyak yang menggunakan pengriman data baik itu file/video sehingga memberatkan siswa dalam kuota. Karna kuota yang diberikan oleh pemerintah lebih banyak untuk video conference ini juga merupakan keluhan dari orang tua siswa. Dengan adanya pelatihan mengenai pengunaan media pembelajaran, semoga bisa membantu remaja di rw 05 kp.kekupu agar terbiasa mengunakan media tersebut untuk kepentingan pembelajaran.

Untuk menyelesaikan masalah yaitu kurangnya pengetahuan remaja dalam menggunakan aplikasi pembelajaran (Zoom, WhatsApp, dan Google Meet) maka kami melakukan sosialisasi dengan Tahapan:

Pertama, tahap persentasi menyampaian materi mengenai materi tentang aplikasi pembelajaran (Zoom, WhatsApp, Google Meet). Materi persentasi berupa teori tentang keliebihan dan kekurangan dari setiap aplikasi (Zoom, WhatsApp, dan Google Meet), cara menggunakan apliksi tersebut. Penyajian Materi persentasi dalam bentuk PowerPoint agar mempermudah dalam pemahaman bagi peserta yaitu remaja karang taruna rw.05 KP. Kekupu. Karena saat ini sosialisasi tidak bisa dilakukan secara langsung. 


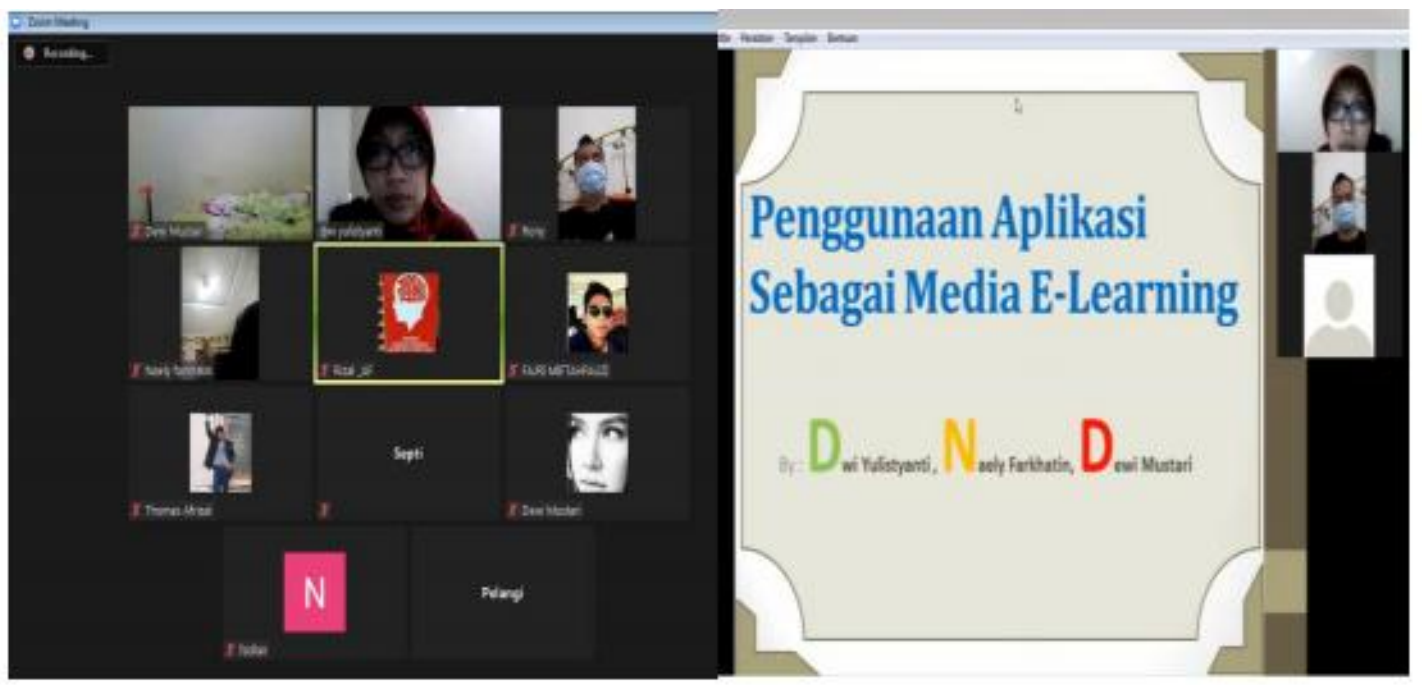

Gambar 1. Penyampain Materi Melalui Media Zoom

Kedua, tanggapan peserta dari 8 orang, 6 orang menyatakan sangat puas dan 2 orang menyatakan puas. Dengan adanya sosialisasi sehingga bisa membantu mereka dalam melaksanakan pembelajaran, 2 orang menyatakan puas. Dengan di laksanakannya kegiatan pengabdian kepada masyarakat yaitu pelatihan pengunaan media pembelajaran menggunakan aplikasi (WhatsApp, Google Meet, Zoom). Dalam pelaksanaannya ada bebeberapa kendala yang dihadapi diantaranya peserta (remaja karang taruna) belum terbiasa menggunakan zoom. Salian itu, kuota pun menjadi kendala dalam pelaksanaan pengabdian masyarakat ini. Namun tim berusaha untuk tetap bisa melaksanan pengabdian ini dengan memberikan bantuan kuota agar peserta dapat mengikuti kegiatan sosialisasi penggunaan aplikasi (WhatsApp, Google Meet, Zoom) untuk pembelajaran. Hasil yang di dapat dari pelatihan tersebut yaitu :

1. Para remaja di RW 05 Kp.Kekupu bisa menggunakan aplikasi pembelajaran dengan baik, sehingga meminimalkan kesalahan dalam mengikuti pembelajaran dari guru nya.

2. Dengan dilaksanakannya pengabdian masyarakat mengenai penggunaan aplikasi (WhatsApp, Google Meet, Zoom) sebagai media pembelajaran, serta sangat membantu remaja untuk digunakan dalam mengikuti kegiatan sharing pengetahuan secara daring.

3. Antusiasme remaja sangat tinggi terhadap materi yang diberikan tim pelaksana abdimas. Hal ini di lihat dari banyak pertanyaan di luar kegiatan abdimas ini yang menginginkan penerapan lebih lanjut dari tim pengabdian masyarakat yang di sosialisasikan sekarang.

4. Tim juga menerapkan hasil dari pelaksanaan kegiatan abdimas ini dalam bentuk draft artikel jurnal PKM dan berharap untuk dapat di publish di jurnal PKM.

\section{PENUTUP}

Dari kegiatan pengabdian masyarakat yang telah dilakukan oleh tim dapat ditarik simpulan sebagai berikut: Pertama dengan adanya pengabdian masyarakat ini, diharapkan dapat membantu permasalahan remaja RW 05 Kp.Kekupu Rangkepan Jaya Depok, mengenai pemahaman dalam penguasaan media pembelajaran yang saat ini digunakan. Kedua dengan adanya pengabdian masyarakat ini, tentunya kami berharap masyarakat bisa memanfaatkan teknologi untuk kepentingan pembelajaran, walaupun memiliki berbagai macam kendala, yang saat ini pembelajaran dilakukan di 
rumah karena sedang pademi sehingga menuntut remaja RW 05 Kp.Kekupu Rangkepan Jaya untuk lebih semangat dan berusaha lagi dalam belajar dengan segala keterbatasan

Pengabdian masyarakat yang dilakukan saat ini agar dapat dipantau hasilnya, pengurus yang menjadi objek pencapaian setelah tim melaksanakan pengabdian masyarakat. Tidak hanya itu remaja RW 05 Kp.Kekupu Rangkepan Jaya Depok bisa konsultasi jika masih kesulitan dalam penggunakan aplikasi (Zoom, WhatsApp, Google Meet).

\section{E. DAFTAR PUSTAKA}

Arsyad, Azhar. 2007. Media Pembelajaran. Jakarta: PT Raja Grafindo Persada.

Madya. 2011. Optimalisasi Pemanfaatan TIK untuk Meningkatkan Mutu Hakiki Pendidikan. Makala Seminar Nasional Milad UAD XXX.

Create or customize a slide master [tersedia online pada] http://office. microsoft.com /en-001/powerpoint-help/create-or-customize-aslide-masterHA010336712.aspx [diakses pada] 15 Januari 2019.

Kisito, Futonge, Lesson- Birthday- How old are you? [tersedia online pada] http://download-esl.com/freepod/birthday.pps [diakses pada] 18 Januari 2019.

MS Power Point 2007; [tersedia online pada] http://smpastra.files.wordpress.com/2010/05/materi-pelatihan-tik-dasar.pdf [diakses pada] 20 Januari 2019.

Oktavian Riskey dan Aldya Riantina Fitra. (2020). Efektivitas Pembelajaran Daring Terintegrasi di Era Pandemi. Jurnal Ilmu dan Pengetahuan. 2(2), hlm.16

Aji, R. H. S. (2020). Dampak Covid-19 pada pendidikan di Indonesia: Sekolah, keterampilan, dan proses pembelajaran. Salam: Jurnal Sosial dan Budaya Syari.(7), 5, 395-402.

CNN Indonesia. (2020). Nadiem terbitkan Surat Edaran Cegah Corona di sekolah. nasional. https://www.cnnindonesia.com/nasional/20200310154954-20482162/nadiem-terbitkan-surat-edaran-cegah-corona-di-sekolah

Ermayulis, S. (2020). Penerapan sistem pembelajaran daring dan luring di tengah pandemi Covid-19.

Pustikayasa, I. M. (2019). Grup WhatsApp Sebagai Media Pembelajaran. Widya Genitri: Jurnal Ilmiah Pendidikan, Agama Dan Kebudayaan Hindu, 10(2), 53-62.

COVID-19, S. (2020, December 25). Ketahui: Adaptasi Kebiasaan Baru. Retrieved December 25, 2020, from https://covid19.go.id/

Haqien, D., \& Rahman, A. A. (2020). Pemanfaatan Zoom Meeting untuk Proses Pembelajaran pada Masa Pandemi Covid-19. SAP (Susunan Artikel Pendidikan), 5(1). doi:10.30998/sapv5i1.6511

QA for public. (n.d.). Retrieved December 24, 2020, from https://www.who.int/indonesia/news/novel-coronavirus/qa/qa-for-public

Yunita, N. W. (2020, March 28). Penyebab, Asal Mula, dan Pencegahan Virus Corona di Indonesia. DetikNews.

Rudi Dian Arifin, (2020, Oktober 14), https://dianisa.com/pengertian-google-meet. 